\title{
STUDENTS' PERCEPTION ON LEARNING LANGUAGE AT THE GRADUATE PROGRAM OF ENGLISH EDUCATION AMIDS THE COVID 19 PANDEMIC
}

\author{
WISMA YUNITA \\ Universitas Bengkulu \\ wismayunita@unib.ac.id \\ IRA MAISARAH \\ Universitas Bengkulu \\ iramaisarah@unib.ac.id \\ DOI : http://dx.doi.org/10.29300/ling.v6i2.3718
}

\begin{abstract}
This research aimed to determine students' perceptions on the implementation of the learning process during the Covid 19 pandemic at the graduate program of English Education of the University of Bengkulu. This research was a descriptive research involving students in academic year of 2019/2020 from two classes consisting of 34 students. The data were taken using a questionnaire in the form of Google form consisting of 40 questions with 5 answer options: strongly agree, agree, neutral, disagree, and strongly disagree and semistructured written interview given through the Google Classroom application. The data obtained were analyzed quantitatively and qualitatively. The results of this research indicate that the students have a positive perception of the implementation of the learning process during the Covid19 pandemic the graduate program of English Education the University of Bengkulu with the average obtained score of 1211.25 which is in the good category. Moreover, the data obtained from the written interview showed that most students gave positive responses to online learning conducted at the graduate program of English education of the University of Bengkulu. These findings are expected to be taken into consideration to improve and prepare for the better future online and offline learning process at the University of Bengkulu, especially at the Graduate Program of English Education of the University of Bengkulu.
\end{abstract}

Keywords: Perception, Online, Offline, Learning, Covid19

\section{INTRODUCTION}

Online learning known as E-learning is the result of a combination of technological advances and education. Ramadhan et al. (2018) said that the collaboration that occurs between technological advances and the learning process results in a learning method called elearning. This type of learning can be used as a solution when distance and time become problems in the learning process. A well-made application design used in this method can make this learning method be a supporting factor in technological advances in education.

It is one of the solutions used by the government to deal with the outbreak that is currently spreading in the world, Covid 19. Covid 19 is a virus that is suspected to have

How to cite this article: Yunita, W., \& Maisarah, I. (2020). Students' perception on learning language ay the graduate program of English education amids the Covid 19 pandemic. Linguists: Journal of Linguistics and Language Teaching, 6(2), 107-120. doi: http://dx.doi.org/10.29300/ling.v6i2.3718 
originated in Wuhan, China. This virus causes mild respiratory infections to acute pneumonia which can cause death. People who are contaminated with this virus have initial complaints such as fever and cough like symptoms of infection in general, but in a more serious phase, the symptoms are accompanied by shortness of breath. The transmission process is very fast, and sometimes it is not accompanied by certain symptoms. Several efforts have been made by the government to minimize Covid 19 spreading, including social distancing, school from home (SFH), and work from home (WFH). This policy causes limited physical contact and social interaction. This obstructs various activities that are usually carried out by the community in public places, one of them is teaching and learning activities.

Not only did it cause many casualties, but the spread of this virus also had a major impact on several sectors in the world, including the education sector. Most of the teaching and learning activities in every educational institution from kindergarten to institutions that involve direct physical contact have been temporarily suspended. This situation causes the learning system's changes where every student must still gain knowledge even though it is constrained by distance and time.

At the college level, such as the University of Bengkulu, the online learning process is the most solution adopt. This activity is carried out through an online learning platform that can be accessed by lecturers and students anytime and anywhere as long as there is an internet connection. It is possible to apply a learning process through this online platform even though the pandemic is currently happening. It makes lecturers and students receive information easier. The response from the application of this online method can be seen from the perceptions conveyed by students.

Students' perceptions of this learning process will vary. This is due to several inhibiting factors that may occur, including internet connections. Perception is a process of individual assessment of an object. According to Triyono \& Febriani (2018) perception has two definitions, namely perception in a broad sense and a narrow sense. In a narrow sense, perception is defined as seeing how each individual sees an object, while in a broad sense perception is defined as a view or understanding, namely how individuals perceive or interpret a particular object. The attitude that a person will take is influenced by the person's perception of the object he is seeing. It means the perceptions of these students may be a factor that affects the understanding of the material presented. Thus it is important to know students' perceptions of a platform used in every online learning process.

In this research, the researcher focused on the students' perceptions on the implementation of the learning process at the Graduate Program of English Education of the University of Bengkulu. The implementation was seen from five indicators namely; the 
students' perceptions on the learning process; the platform used and the interaction model; the materials, methods, and tools or learning media; learning resources, evaluation, and learning support; and the type of platforms used and the problems faced by the students in the learning process carried out at the Graduate Program of English Education of the University of Bengkulu. The results of this research are expected to be taken into consideration for the optimization of the online learning process at the University of Bengkulu, especially at the Graduate Program of English Education.

\section{Perception}

Perception is the process of giving meaning to the environment by an individual. Perception is also defined as a response or judgment about an object that is produced based on a person's experience and knowledge. Normadewi (2020) said that the notion of perception is an activity that involves a cognitive process for understanding the environment that includes objects and symbols or signs.

Perception can be described as someone's expectation of an object, such as people, institutions, agencies, and others. Akbar (2015) states that if someone wants to know the desires and expectations of the community about an educational institution, he can do it by knowing the community's perception of an educational institution. Knowing a person's perceptions can be a supporting factor in efforts to improve quality.

\section{Learning Process}

The learning process is an activity that occurs as an effort to apply the knowledge provided by teachers to students. Suhanji (2014) said that the learning process is an attempt to look at behavior changes of students through a process called learning and this situation is an event of learning. Two processes occur in the learning process, namely learning and teaching. As explained by Widoyoko (2009) who argues that learning is a translation of the word "instructional" which consists of two words, namely learning and teaching.

The definition of learning itself is a change that occurs in students towards a better direction. The changes might be happened in understanding the material or other to support students' optimizing abilities, while the teaching itself is a process carried out by conditioning the atmosphere around students in the efforts to bring an expected change. Furthermore, Pane \& Dasopang (2017) said that the process of regulating, organizing the environment around students so that it can encourage students to do the process of gaining new knowledge is called learning.

The learning process is carried out to achieve a certain goal. The process is expected to have a positive impact on students to achieve the expected goals. In this context, the teachers direct the students to achieve practical goals in formal education sense and to have selfawareness in order to lead the students to a better learning (Yuzulia, 2020). Likewise, Nadzir Linguists: Journal of Linguistics and Language Teaching Vol. 6, No. 2, December 2020 
(2013) states that the context of learning means whenever the teacher provides a series of activities that have been conceptualized on the expected goals and then these activities are acknowledged by the students. To achieve this goal, it takes collaboration between learning components. The components in the learning process are educational objectives, students, educators, materials or subject matters, approaches and methods, media or tools, learning resources, and evaluations (Pane \& Dasopang, 2017).

\section{Online Learning Process}

Online learning (e-learning) is a learning process that is carried out without face to face meeting and is not in the classroom as usual but is carried out in some virtual rooms and interacts virtually using the internet network. Ramadhan et al (2018) said that online learning eliminates the problem of distance and time, and e-learning is a learning process that is carried out online and can be in the form of synchronous or asynchronous. In line with the opinion expressed by Mahendra et al. (2019) who say that in digital communication there is a material that studies synchronous and asynchronous communication.

This learning process is a collaboration that occurs between technological advances and the learning process which called e-learning. Optimizing the planning and use of this method will greatly help improve the world of education. Basically, e-learning is the optimization of learning events assisted by appropriate information and communication technology. (Chaeruman, 2017).

\section{Synchronous and Asynchronous communication}

Communication in the learning process can be done synchronously and asynchronously. Synchronous communication is communication for the learning process that is carried out using communication technology and both users have an internet connection at the same time, where both users can exchange information directly without having to wait for a reply. This learning activity is usually carried out using a computer or gadget. Synchronous elearning requires direct instruction during the learning process by the instructor. (Ramadhan et al, 2018). The example of applications that applies synchronous communication are zoom and skype. Asynchronous learning is an online learning that is carried out without involving real-time communication. The communication is delayed because both users are not online at the same time. The example of asynchronous communication is sending an email or using online website for learning.

\section{Online Learning Platform}

The learning platform is an intermediary media used in learning activities. It can be done through several online applications. The results of the learning from home survey (DaRum) conducted by the Directorate General of Higher Education of the Ministry of Education and 
Culture with the network of universities providing medical education and the Association of State Higher Education Hospitals resulted in several platforms that are often used in online learning. The platform are Cisco Webex, Zoom, Skype, Google classroom, VClass, Webinar, Facebook Live, and Youtube Live.

\section{Covid 19}

Covid-19 is a virus that spreading in the world recently. In a short period, this virus caused many casualties. This virus was first detected in Wuhan, China. Coronavirus infection is not the first time. Yuliana (2020) said that infection from this virus occurred in 2002 which was caused by SARS-coronavirus and this disease was later known as a severe acute respiratory syndrome (SARS) and has also occurred in 2012 with the name Middle East Respiratory Syndrome ( MERS).

The coronavirus includes the biota superdomain, virus kingdom. This virus is the largest group of viruses of the Nidovirales. All viruses of the Nidovirales are non-segmented positive-sense RNA viruses. The Coronavirus is included in the Coronaviridae family, the Coronavirinae sub-family, the Betacoronavirus genus, the Sarbecovirus subgenus (Parwanto, 2020). As time passed by, this virus spread to all parts of the world causing the death toll from this virus to continue to increase.

This virus causes mild respiratory infections to acute pneumonia which caused death. Patients contaminated with this virus have initial complaints such as fever and cough as symptoms of infection in general, but in a more serious phase, the symptoms are accompanied by shortness of breath. Various efforts have been made to reduce the spread of Covid-19. The efforts made include social distancing, school from home (SFH), and work from home (WFH). With these policies, several sectors in the world have been disrupted, including the education sector. To adapt to these conditions, learning is carried out online.

\section{Previous Findings}

Online learning provides positive benefits for learning process. The students' perception of online learning are also good. It can be concluded based on some of previous studies. Research on perceptions of online learning has been conducted by several researchers. However, there is not many research conducted in the field of English language teaching. The first research was conducted by Sobron, Bayu, Rani, \& Meidawati (2019) at Bangun Veteran Nusantara University. The results showed that the learning process using online learning in science subjects made students enthusiastic and do not feel bored in learning science.

Subsequent research was carried out by Maskar \& Wulantina (2019) at the Teknorat University of Lampung. The results showed that the students felt the learning process with the Blended Learning Method through Google Classroom made the learning process interesting, effective, increased the learning motivation, students' independence, active, and Linguists: Journal of Linguistics and Language Teaching Vol. 6, No. 2, December 2020 
creative learning attitudes. Moreover, this method can also improve students' understanding and learning outcomes. However, students feel the learning process was inefficient because it required them to have a internet connection.

Other research was conducted by Zhafira, Ertika, \& Chairiyaton (2020) at Teuku Umar University. The results of the study reveal that the most popular online learning media are WhatsApp and Google Classroom. As much as 53\% of the students of the Faculty of Economics, Teuku Umar University are already familiar with various online learning media before online lectures begin. In addition, the most students' interested communication was the semi-bidirectional communication pattern.

Research related to learning English was conducted by Khusniyah \& Hakim (2019). The results of this study indicated that there was a difference on students's ability to understand English text before and after using a web blog. In this case, online learning assisted by the web blog has a positive effect on improving students' English reading skills.

\section{METHOD}

This research was a descriptive research that used quantitative and qualitative approaches. The aim of this research is to determine student perceptions on the implementation of online learning process during the Covid19 pandemic at the Graduate Program of English Education at the University of Bengkulu.

\section{Respondents}

The respondents of this study were the students of the Graduate program of English Education of the University of Bengkulu consisting of 34 students. These students were taking the courses at the third semester and their age level are around 20-45 years old.

\section{Instruments}

The instrument of this study was a questionnaire with 40 items given to 34 students (total sampling) by using Google form. The questions had five 5 answer options: strongly agree, agree, neutral, disagree, and strongly disagree. The questionnaire used in this study was adapted from the learning survey of the Director General of Higher Education, Ministry of Education and Culture. The questions covering five indicators: the students' perceptions on the learning process; the platform used and the interaction model; the materials, methods, and tools or learning media; learning resources, evaluation, and learning support; and the type of platforms used and the problems faced by the students in the learning process carried out at the Graduate Program of English Education of the University of Bengkulu. 


\section{Procedures}

The procedure of the research were: first, the researchers prepared the research instruments (questionnaire and question of written interview). Then, the researcher asked the respondent to fill out a questionnaire that was already available through the Google Form application. Next, the researcher chose 13 students randomly as the sample to conduct a written interview through the Google Classroom. After that, the results obtained from filling out the questionnaires and written interviews were analyzed. Finally, the research results were being interpreted and conclusions were drawn from the data.

\section{Data analysis}

The data in this study was quantitative data which are analyzed quantitatively by first looking for the intervals of the lecturer perception category using the Humberg formula. The formulas, intervals and categories of student perceptions are determine based on the formula and range from very bad (34-61.2), bad (61.3-88.4), fair (88.5-115.6), good (115.7-142.8) and very good (142.9-170). Meanwhile, the qualitative data in sentences and paragraphs form was analyzed qualitatively using Miles and Huberman (1994) which consisted of data reduction, data display, and conclusion and verification (clonclusion drawing/verification). At the data reduction stage, the researcher read the data in the form of responses from 13 respondents and then makes notes about these responses and classifies them. Furthermore, at the data presentation stage (data display) the researcher presented the data obtained from written interviews in the form of sentences that support the data obtained from the questionnaire so that the data obtained from the results of the questionnaire and the results of the written interviews appear to be directly proportional. In the last stage, namely drawing conclusions and verification (conclusion drawing/verification), the researcher concluded the results of the written interview as a whole.

\section{FINDINGS AND DISCUSSION}

This section presented the result of this research. The results of this research indicated students' positive perceptions on the implementation of learning process at the Graduate Program of English Education of the University of Bengkulu. It can be shown by the results of filling out a questionnaire which obtained an average score of 1211.25 for 40 items from the five indicators of the items that were responded to. Nevertheless, 40 items were produced in the form of statements. The average score is in a good category. The questionnaire items were measured with statistical-numerical results ranging from 5-1: 5 (Strongly agree), 4 (Agree), 3 (Neutral), 2 (Disagree), and 1 (Strongly disagree). The results of the research for each indicator are presented in the table below. 
Table 1. Students' Perception on Learning Language at Graduate Program of English Education Amids the Covid 19 Pandemic

\begin{tabular}{|c|c|c|c|c|c|c|c|c|c|c|c|c|c|c|c|}
\hline \multirow{3}{*}{ No } & \multirow{3}{*}{ Items' Indicator } & \multirow{3}{*}{$\mathrm{N}$} & \multirow{3}{*}{$\begin{array}{l}\text { Num } \\
\text { ber } \\
\text { of } \\
\text { item }\end{array}$} & \multicolumn{8}{|c|}{ Statements' Criteria } & & & \multirow{3}{*}{ Score } & \multirow{3}{*}{ Category } \\
\hline & & & & \multicolumn{2}{|c|}{ SA (5) } & \multicolumn{2}{|c|}{ A (4) } & \multicolumn{2}{|c|}{ Neutral (3) } & \multicolumn{2}{|c|}{$\begin{array}{c}\text { Disagree } \\
\text { (2) }\end{array}$} & \multicolumn{2}{|c|}{$\begin{array}{c}\text { Strongly } \\
\text { Disagree } \\
\text { (1) }\end{array}$} & & \\
\hline & & & & $\mathrm{F}$ & score & $\mathrm{F}$ & Score & $\mathrm{F}$ & Score & $\mathrm{F}$ & score & $\mathrm{F}$ & score & & \\
\hline 1 & $\begin{array}{c}\text { The Learning } \\
\text { Process }\end{array}$ & & 10 & 58 & 290 & 176 & 704 & 51 & 153 & 45 & 90 & 10 & 10 & 1247 & Good \\
\hline 2 & $\begin{array}{l}\text { The platform } \\
\text { used and the } \\
\text { interaction } \\
\text { model }\end{array}$ & 34 & 10 & 34 & 170 & 168 & 672 & 69 & 207 & 58 & 116 & 11 & 11 & 1176 & Good \\
\hline 3 & $\begin{array}{l}\text { The Materials, } \\
\text { methods, and } \\
\text { tools or learning } \\
\text { media }\end{array}$ & & 11 & 58 & 290 & 201 & 804 & 65 & 195 & 42 & 84 & 8 & 8 & 1381 & Good \\
\hline 4 & $\begin{array}{l}\text { The learning } \\
\text { resources, } \\
\text { evaluation, and } \\
\text { learning support }\end{array}$ & & 9 & 35 & 175 & 126 & 504 & 80 & 240 & 57 & 114 & 8 & 8 & 1041 & $\begin{array}{l}\text { Quite } \\
\text { Good }\end{array}$ \\
\hline & Total score & & 40 & & & & & & & & & & & $\begin{array}{c}4845: 4= \\
1211.25\end{array}$ & Good \\
\hline
\end{tabular}

The data above clearly showed the students' perceptions on the five indicators mentioned previously. This research showed that all students show positive perceptions on the learning process using an online platform carried out at the Graduate program of English Education of the University of Bengkulu almost in all aspect. To support the quantitative data from questionnaires, the researchers also strengthen the data by using the data obtained from the written interviews. Based on these results, the data on the types of online platforms used and the obstacles faced by students in the learning process were obtained. For a more detail description on the students' perceptions for each of these indicators, it will be described in the following sections.

\section{Students' perceptions on the Learning Process at the Graduate Program of English Education of the University of Bengkulu}

Students' perceptions on the online learning process at the Graduate Program of English Education of the University of Bengkulu are in a good category. On the table 1 above, it can be seen that the total score for learning process on the questionnaire filled out by 34 students show an average score of 125.5 and it is in a good category. These results were supported by the results of written interviews which showed that most students gave positive responses about this online learning. This can be seen from the responses of respondent R3-EH who said "My impression of using this Platform in the learning process during SFH / Covid 19 period provides benefits to students who can still learn even amid this pandemic" (R3-EH). 
This research has the same results as the results of research conducted by Saifuddin (2017) regarding e-learning in the perceptions of biology students of the Faculty of Teacher Training and Education, class 2015 and 2016, which concluded that most students expressed support and satisfaction with the implementation of e-learning. It might happened because online learning has advantages for both students and lecturers. For students, online learning is considered as an alternative method of learning that does not require them to attend class. Online learning can also help students establish independent learning and also encourage interaction between students. Whereas for lecturers, online learning methods can be used as a way to change conventional teaching styles which will indirectly have an impact on work professionalism. The online learning method also provides more opportunities for lecturers to more efficiently assess and evaluate the learning progress of each student (Zhafira, Ertika \& Chairiyaton, 2020).

This good perception given by students towards online learning might increase the student activity in the learning process. This is supported by Nugroho's (2012) who argues that perception greatly affects the increase in role and activeness of students in using media and technology for the success of online lectures. Moreover, the results of this research indicated that some students agreed that the learning process through online platforms provided benefits for mastery of technology use. The online learning process is a learning process that utilizes digital technology as a medium for knowledge transfer (Anhusadar, 2020).

On the other hand, the results of this research are different from Adijaya \& Santosa (2018) who concluded that most students stated that the interactions that occur in online learning do not help them in the learning process. It might happened because unbalanced interactions between students and students as well as between lecturers and students because interactions play an important role in the learning process. It is supported by the statement of Lin \& Lin (2015) who stated that to improve communication and discussion about every activity in the teaching and learning process, student interaction with students and lecturers must always be built.

\section{Students' Perceptions on the Online Platforms and Interaction Model Used by} Lecturers in online Learning Process at the Graduate Program of English Education of the University of Bengkulu

The table 1 above showed that the use of various online learning platforms by the lecturer is in the good category with an average score of 117.6. The platforms used by lecturers vary widely. The platform is delivered using synchronization communication such as zoom and/or by asynchronous communication such as email. Learning is carried out Linguists: Journal of Linguistics and Language Teaching Vol. 6, No. 2, December 2020 
regularly with the delivery of clear material. From the data collected from the questionnaire, it can be seen that the interaction models that are often carried out by the lecturers on average fall into the good category. Model interaction that is often carried out with a mixed model is the direct face-to-face interaction model through zoom as one of the platforms used and the non-face-to-face interaction model through one of the social media, namely WhatsApp or google classroom. It might be happened because the lecturer made more variations so that the students don't feel bored with the same model interaction used.

\section{Students' perceptions on The Materials, Methods, and Tools or Learning media at the Graduate Program of English Education of the University of Bengkulu}

As illustrated on the table 1 above, it can be concluded that perceptions on the Materials, Methods, and Tools or learning media at the Graduate Program of English Education of the University of Bengkulu showed a positive result with an average score of 125.5 which was in the good category. It was in line with the results obtained through written interviews which showed that most respondents gave good responses as said by respondent R2-EJ: "In general, you can say yes. Learning with a system like this is not limited by space and time, so it provides opportunities for students to ask a lot of questions and discuss it "(R2-EJ). Similar expressions were conveyed by another respondent as can be seen in the following expressions: "Yes, because in using the Platform we are also guided by lecturers of the course, so the material is conveyed well". (R13-YA).

Furthermore, the results of this research indicated that most students said that the material conveyed through online learning can be understood and learning becomes meaningful. This is the same as the results of research conducted by Anhusadar (2020) which concluded that the material presented through online learning can be understood by students.

\section{Students' Perception on The Learning Resources, Evaluation, and Learning Support of the Online Learning Process at the Graduate Program of English Education of the University of Bengkulu}

Based on the table 1 above, it can be concluded that the students' perceptions on learning resources, evaluation, and learning support used at the Graduate Program of English Education of the University of Bengkulu on average are in a fair category with an average score of 114.5. This fair category especially on the evaluation and learning support indicators. It might happened because the evaluation did not maximize because the lecturer cannot directly monitor the ongoing learning process which is caused by several limitations, such as the limited image quality in the video with a small size and it is difficult to monitor 
everything carefully. Besides, the network limitations sometimes caused learning through direct interaction via video for each meeting is difficult to be held.

However, the learning resources are in the good category. Some respondents said that learning through online platform was meaningful. This is supported by the results collected by written interviews with respondents R9-RD who said that the online learning process was very meaningful. "In my opinion, the use of the Platform in the learning process during SFH is very meaningful, all discussions can be carried out freely, without time limit. Discussions probably held anytime and anywhere. Besides, the use of this platform allows all learning processes (discussions) to be accessed again at a later time because they are automatically saved on the platform "(R9-RD).

\section{The Types of Online Platform Used and the Problems Faced by Students at the Online Learning Process at the Graduate Program of English Education of the University of Bengkulu}

The online platforms used by lecturers at the Graduate Program of Education of the University of Bengkulu were vary. The results collected by written interviews with 13 students showed the same results. Respondent R2-EJ said that the types of online platform used are Zoom, Google Classroom, Email, WhatsApp, WhatsApp Group, and Edmodo. The results of a written interview to R5-F explains more detail on the type of platform used in each course. In the Sociolinguistics course, lecturers used WhatsApp. In the EFL Curriculum Analysis lecturers used WhatsApp and in the ELT Methodology and Innovation course lecturers used WhatsApp and Google Classroom. Meanwhile, the English Teaching Material Development course used Google Classroom and the Advance Translation course used WhatsApp and Edmodo.

This result is the same as the research conducted by Zhafira, Ertika \& Chairiyaton (2020) in the use of the WhatsApp Group, Google classroom, Zoom, Email, Edmodo, and Google Meet applications in the online learning process and Anhusadar (2020) which uses WhatsApp Group, Zoom, and Email. This research is slightly different from the research conducted by Saifuddin (2017) which in his research the learning application used is Google classroom, Edmodo, Moodle, Quipper, and Schoology. This difference might happened because the use of online learning platforms is adjusted to the material being taught and the context of learning.

From this research, it was also found that there were problems in online learning. Based on the data collected by written interviews, it can be concluded that most students experienced almost similar problems in the learning process using online platforms during the SFH / Covid-19 period. These problems include the instability of the internet and electricity Linguists: Journal of Linguistics and Language Teaching Vol. 6, No. 2, December 2020 
networks. This was also stated by Handayani (2020) who said that one of the problems that caused online learning dissatisfaction was the instability of the internet network.

\section{CONCLUSION}

Based on the results obtained from the previous section, it can be concluded that the perceptions of students at the Graduate Program of English of the University of Bengkulu towards online learning are in a good category. The results show that the learning with online platforms helped them during this pandemic. In addition, learning using this online platform also has a positive impact on the use of technology, in which the variety of platforms used by the lecturers makes the students know better and more familiar with the use of online learning platforms applied in daily activities. The problems faced by students in the learning process through this online platform are the instability of the internet connection and the outages power in their location.

\section{REFERENCES}

Adijaya, N., \& Santosa, L. P. (2018). Persepsi Mahasiswa dalam Pembelajaran Online. Wanastra, 10(2), 55-60.

Akbar, F. R. (2015). Analisis Persepsi Pelajar Tingkat menengah Pada Sekolah Sekolah Tinggi Agama Islam Negeri Kudus. Jurnal Penelitian Pendidikan Islam, 10 (1), 189219.

Anhusadar, O., L. (2020). Persepsi Mahasiswa PIAUD terhadap Kuliah online di Masa Pandemi Covid 19. Journal of Islamic Early Childhood Education. 3, 44-58.

Chaeruman, U., A. (2017). Alur Belajar: Meningkatkan Interaktivitas Pembelajaran Daring. Seminar dan Lokakarya Pembelajaran Daring di Perguruan Tinggi. Diakses dari https://www.researchgate.net/publication/323676111_Alur_Belajar_Meningkatkan_Inter aktivitas_Pembelajaran_Daring

Handayani, L. (2020). Keuntungan, kendala dan Solusi Pembelajaran Online Selama Pandemi Covid-19 : Studi Eksploratif di SMPN 3 Bae Kudus. Journal Industrial Engineering \& Management Research (JIEMAR), 1

Khusniyah, n., \& Hakim, 1. (2019). Efektivitas Pembelajaran Berbasis Daring: Sebuah Bukti Pada Pembelajaran Bahasa Inggris. Jurnal Tatsqif, 17(1), 19-33. https://doi.org/10.20414/jtq.v17i1.667

Lin, E., \& Lin, C. H. (2015). The Effect of Teacher Student Interaction on Students ' Learning Achievement in Online Tutoring Environment. International Journal of Technical Research and Applications. 22(22), 19-22

Mahendra, D. Y. \& Mariono, A. (2019). Pengembangan Media e-Modul Berbasis Aplikasi Android Materi Komunikasi Sinkron dan Asinkron Dalam Jaringan Mata Pelajaran Simulasi dan Komunikasi Digital Kelas X Multimedia di SMK Negeri 1 Sooko Mojokerto. Jurnal Mahasiswa teknologi Pendidikan. 9 (2). 
Maskar, S. \& Wulantina, E. (2010), Persepsi Peserta Didik terhadap Metode Blended Learning dengan Google Classroom. Jurnal Inovasi Matematika (Inomatika). 1(2), 110121.

Miles, M. B., \& Huberman, A. M. (1994). Qualitative Data Analysis An Expanded Sourcebook. Thousand Oaks, CA Sage Publications.

Nadzir, M. (2013). Perencanaan Pembelajaran Berbasis Karakter. Jurnal Pendidikan Agama Islam. 2 (2). 339-352

Normadewi, B. (2012). Analisis Pengaruh Jenis Kelamin terhadap persepsi Etis Mahasiswa Akuntansi Dengan Love of Money sebagai Variabel Intervening. Universitas Negeri Semarang.

Nugroho. (2012). Profesionalisme Guru SD Negeri Se-Kecamatan Warungasem Kabupaten Batang. Suatu tinjauan aspek persepsi guru tentang kepemimpinan kepala sekolah dan motivasi berprestasi guru. Varidika , 135-146

Pane, A. \& Dasopang, M. D. (2017). Belajar dan Pembelajaran. FITRAH Jurnal Kajian Ilmu-Ilmu Keislaman, 3 (2), 333-352.

Parwanto, MLE. (2020). Virus Corona (2019-nCoV) Penyebab Covid-19. Jurnal Biomedia dan Kesehatan, 3 (1). 1-2.

Ramadhan, R., Chaeruman, U., A., \& Kustandi, C. (2018). Pengembangan Pembelajaran Bauran (Blended Learning) di Universitas Negeri Jakarta, Jurnal Prodi teknologi Pendidikan FIP UNJ.1 (1), 37-48.

Saifuddin, M. F. (2017). E-Learning Dalam Persepsi Mahasiswa. Varia Pendidikan. 29, 102109.

Sobron A.N, Bayu, Rani, \& Meidawati, S., (2019). Persepsi Siswa Dalam Studi Pengaruh Daring Learning Terhadap Minat Belajar Ipa.. SCAFFOLDING: Jurnal Pendidikan Islam dan Multikulturalisme, 1 (2), 30-38.

Suhanji. (2014). Konsep Manajemen Kelas dan Implikasinya Dalam Pembelajaran. Jurnal Pendidikan. 11 (2), 30-46.

Triyono, \& Febriani, D. R. (2018). Persepsi Peserta Didik Sekolah Menengah Atas Terhadap Pendidikan Lanjutan. Jurnal Pendidikan dan Pembelajaran, 3 (1), 70-77.

Widoyoko, E. P. (2009). Evaluasi Program Pembelajaran. Yogyakarta: Pustaka Pelajar.

Yuliana. (2020). Corona virus disease (Covid-19); Sebuah tinjauan literatur. Wellness and Healthy Magazine. 2 (1), 187-192.

Yuzulia, I. (2020). EFL Teachers' Perceptions and Strategies in Implementing Learner Autonomy. Linguists: Journal Of Linguistics and Language Teaching, 6(1). doi:http://dx.doi.org/10.29300/ling.v6i1.2744

Zhafira, NH, Ertika, Y., \& Chairiyaton. (2020). Persepsi Mahasiswa Terhadap Perkuliahan Daring Sebagai Sarana Pembelajaran Selama Masa Karantina Covid-19. Jurnal Bisnis dan Kajian Strategi Manajemen, 4 (1), 37-45.

\section{Acknowledgement}

Linguists: Journal of Linguistics and Language Teaching

Vol. 6, No. 2, December 2020 

The writers would like to express their gratitude and appreciation to the Faculty of Teacher Training and Education of the University of Bengkulu for funding the research through the faculty research grant of the 2020 scheme with the contract number of 9204/UN30.7/HK/2020 dated 29 July 2020. In addition, the writer would also like to thanks all the third semester students of the Graduate Program of English Education of the University of Bengkulu for their participation in this research. 